\title{
GIZI DALAM KEHAMILAN : STUDI LITERATUR
}

\author{
Intan Gumilang Pratiwi ${ }^{1 *}$, dan Baiq Yuni Fitri Hamidiyanti ${ }^{1}$ \\ ${ }^{1}$ Jurusan Kebidanan, Poltekkes Kemenkes Mataram, Indonesia \\ Jl. Kesehatan V/10 Mataram \\ Email : intangumil@gmail.com
}

\begin{tabular}{l} 
Article Info \\
\hline Article history: \\
Received January $2^{\text {th }}, 2020$ \\
Revised February $5^{\text {th }}, 2020$ \\
Accepted March $30^{\text {th }}, 2020$ \\
\hline
\end{tabular}

\section{Kata Kunci :}

Gizi; Kehamilan.

\begin{abstract}
ABSTRAK
Background : Ibu hamil perlu memperhatikan asupan nutrisi yang dikonsumsi. Bukan hanya memenuhi makanan dan minuman namun haruslah mengandung angka kecukupan gizi yang cukup dan seimbang
\end{abstract}

Research Methods : Studi literature ini dengan metodemengumpulkan data dari studi pencarian sistematis database terkomputerisasi (PubMed, BMC, Cochrain review, Google cendekia) berbentuk jurnal penelitian dan artikel review dalam lima tahun terakhir dengan kata kunci gizi ibu hamil dan prenatal nutrittion Proses studi literature ini melalui proses awal formulasi permasalahan, pencarian artikel, evaluasi data serta menganalisis dan menginterpretasikan.

Research Result : Wanita hamil harus fokus pada kualitas diet dan didorong untuk memilih makanan kaya nutrisi yang kaya akan makronutrint maupun micronutrient. Mitos makan untuk berdua (ibu dan janin) harus dihilangkan, rekomendasi gizi seimbang disesuiakan dengan kebutuhan nutrisi selama hamil sesuai dengan indeks massa tubuh ibu sebelum hamil.

Copyright $\odot$ Jurnal Gizi Prima All rights reserved.

\section{PENDAHULUAN}

Masa kehamilan merupakan masa terpenting bagi siklus kehidupan wanita. Selama hamil seorang perempuan tidak hanya memberikan nutrisi bagi dirinya sendiri namun bagi dirinya dan janin. Selama kehamilan setidaknya wanita membutuhkan kalori sekitar 400 kkal. Peningkatan kebutuhan tersebut setidaknya $15 \%$ dari yang dikonsumsi biasanya atau dalam keeharian. Kebutuhan tersebut $40 \%$ bagi janin dan $60 \%$ bagi ibu. Ibu hamil perlu memperhatikan asupan nutrisi yang dikonsumsi. Bukan hanya memenuhi makanan dan minuman namun haruslah mengandung angka kecukupan gizi yang cukup dan seimbang. Jika gizi selama kehamilan tidak terpenuhi maka akan mengakibatkan kekurangan gizi yang dikenal sebagai KEK (kurang energy kalori) hingga dampak buruknya pertumbuhan janin yang tidak sempurna serta kecacatan janin. (de Seymour, Beck, \& Conlon, 2019)

Asupan makanan selama hamil berbeda dengan asupan sebelum masa kehamilan untuk memenuhi kebutuhan ibu dan janin, berdasarkan angka kecukapan gizi (AKG) tahun 2013 diperlukan tambahan 300 kkal perhari selama kehamilan. Penambahan protein 20gr/hari, lemak 10g/hari dan karbohidrat 40g/hari selama kehamilan serta mikronutrisi lainnya untuk membantu proses pertumbuhan janin didalam kandungan. Pertumbuhan dan perkembangan janin ini sangat dipengaruhi oleh asupan gizi ibu selama hamil. Jika keadaan kesehatan dan status gizi ibu hamil baik, maka kesehatan ibu dan janin yang dikandungnya akan baik pula, sebaliknya jika keadaan kesehatan dan status gizi ibu hamil kurang baik (anemia) maka dapat meyebabkan janin lahir mati atau bayi lahir dengan berat badan kurang dari normal/low birth weight. Asupan gizi yang cukup sangat dibutuhkan oleh ibu hamil, kebutuhan gizi ini diperlukan ibu hamil untuk dapat memberikan nutrisi yang baik kepada janin untuk pertumbuhan dan perkembangan janin didalam kandungan. Pertumbuhan janin dan berat lahir bayi ini dipengaruhi oleh asupan gizi yang dikonsumsi ibu selama masa kehamilan. Asupan nutrisi yang baik pada ibu hamil akan menghindari terjadinya malnutrisi pada ibu, jika berlanjut akan berdampak buruk pada perkembangan janin 
dimana dapat menjadi berat badan lahir rendah atau berlebih. (Marangoni et al., 2016)

Prevalensi Kurang Energi Kronis (KEK) pada ibu hamil di Indonesia menurut Riskesdas Tahun 2018 sebanyak 17,3\%. Berdasarkan penelitian yang dilakukan S.Mila, 2015 peran asupan pada saat hamil berupa makronutrient seperti karbohidrat, lemak sangat memengaruhi berat badan lahir bayi. Kekurangan nutrisi pada zat gizi protein dan energi pada ibu hamil dapat mengurangi inti dari DNA dan RNA dan dapat menganggu profil asam lemak sehingga transfer zat gizi ibu kejanin menjadi terganggu. Ukuran otak juga berkurang pada mekanisme ini sebagai akibat dari perubahan struktur protein, konsentrasi faktor pertumbuhan dan produksi neurotransmiter. Malnutrisi pada protein dan energi terjadi pada minggu ke 2444 pasca konsepsi dapat terjadi di dalam uterus maupun di luar uterus hal ini dapat mengakibatkan pertumbuhan janin terhambat. Pertumbuhan janin terhambat ini juga berakibat pada buruknya pertumbuhan kepala pada masa prenatal yang dapat berhubungan dengan buruknya keluaran perkembangan saraf. (Kementerian Kesehatan RI, 2018; Syari, Serudji, \& Mariati, 2015)

Mengingat ibu hamil merupakan kelompok yang harus diperhatikan kecukupan gizinya, makanan yang dimakan akan memengaruhi keadaan kesehatan dan kesehatan janin yang dikandungnya, maka sesuai dengan latar belakang diatas penulis melakukan studi literatur gizi seimbang pada ibu hamil.

\section{METODE PENELITIAN}

Studi literature ini dengan metode mengumpulkan data dari studi pencarian sistematis database terkomputerisasi (PubMed, BMC, Cochrain review, Google cendekia) berbentuk jurnal penelitian dan artikel review dalam lima tahun terakhir dengan kata kunci gizi ibu hamil dan prenatal nutrittion Proses studi literature ini melalui proses awal formulasi permasalahan, pencarian artikel, evaluasi data serta menganalisis dan menginterpretasikan.

Tabel 1. Strategi Pencarian pada data based

\begin{tabular}{c}
\hline Langkah pencarian artikel melalui data based \\
\hline Prenatal or Nutrition \\
\hline Gizi or ibu hamil \\
\hline$\# 1$ and \#2
\end{tabular}

\section{HASIL PENELITIAN}

Berthold Koledzo dkk (2019) dalam artikelnya berjudul Nutrition during pregnancy, lactation and early childhood menjelaskan bahwa wanita hamil harus mengkonsumsi diet seimbang sesuai dengan rekomendasi diet untuk populasi umum. Mereka harus meningkatkan asupan energi makanan pada akhir kehamilan dengan tidak lebih dari $10 \%$ di atas resep asupan energi yang direkomendasikan pada wanita tidak hamil. Baru-baru ini fokus nutrisi dalam kehamilan berkaitan dengan masalah obesitas, , terutama diabetes gestasional dan makrosomia janin, potensi dampak jangka panjang pada kesehatan keturunan umumnya tidak dihargai. Peneliti Nutrisi Dini, antara lain, telah melaporkan asosiasi independen obesitas ibu, kenaikan berat badan yang berlebihan, serta diet pada kehamilan dengan adipositas masa kanak-kanak dan indikator risiko kardiovaskular Karena hubungan ini dan pengaruh defisiensi mikronutrien pada perkembangan janin dan kesehatan anak, fokus pada status gizi dalam kehamilan adalah sangat penting tidak hanya untuk kesehatan ibu, tetapi juga keturunannya. Kecuali nutrisi pra-kehamilan kurang optimal, keseimbangan makronutrien dalam makanan tidak perlu berubah dalam kehamilan. Pada awal kehamilan, kebutuhan energi sedikit berbeda dari pra-kehamilan. Fokusnya harus pada makan makanan sehat dengan makanan kaya nutrisi kritis, daripada makan lebih banyak Konsep makan untuk berdua yaitu ibu dan janin adalah mitos yang harus dibuang. (Koletzko et al., 2019)

Untuk wanita dengan BMI normal $(<25 \mathrm{~kg} / \mathrm{m} 2)$, peningkatan asupan energi diperlukan hanya setelah kehamilan untuk meningkatkan kebutuhan metabolisme yang dibutuhkan ibu dan kebutuhan energi janin yang sedang tumbuh. Rekomendasi internasional menyarankan bahwa selama kehamilan, wanita meningkatkan asupan energi mereka sekitar $85 \mathrm{kkal}$ per hari pada trimester pertama, $285 \mathrm{kkal}$ per hari pada trimester kedua dan $475 \mathrm{kkal}$ per hari pada trimester ketiga. Namun, khususnya pada trimester ketiga, tingkat aktivitas fisik cenderung berkurang, sehingga asupan makanan biasanya tidak perlu meningkat lebih dari sekitar $10 \%$ pada akhir kehamilan, relatif terhadap kebutuhan sebelum kehamilan. Faktor-faktor yang mungkin mengindikasikan kebutuhan energi yang lebih besar termasuk kehamilan remaja (ketika ibu memiliki pertumbuhan yang menuntut nutrisi yang tersedia), kerja fisik yang keras / aktivitas fisik yang 
tinggi, kehamilan ganda, dan infeksi atau gangguan malabsorpsi, yang mungkin mengurangi penyerapan dan pemanfaatan nutrisi. Penelitian lebih lanjut diperlukan pada metabolisme energi dan asupan energi optimal dalam kehamilan sehubungan dengan hasil kesehatan ibu dan anak jangka panjang. (Koletzko et al., 2019)

Jamie V et all (2019) dalam sebuah reviewnya berjudul nutrition in pregnancy mengemukakan bahwa Sebuah mitos umum yang perlu dihilangkan adalah bahwa ibu hamil harus 'makan untuk berdua'. Mungkin ada efek merugikan bagi kesehatan janin dan ibu dari makan melebihi persyaratan. Rekomendasi asupan energi selama kehamilan di Inggris adalah untuk menambah asupan sekitar 200 kalori (sekitar 837 kilojoule) per hari dan hanya pada trimester ketiga. Tambahan 200 kalori kira-kira setara dengan menambahkan pisang dan pot yogurt ke dalam makanan biasa. Rekomendasi ini didasarkan pada asumsi bahwa pertumbuhan janin dan kenaikan berat badan kehamilan tetap dalam parameter yang sehat, sehingga pemantauan keduanya selama kehamilan sangat penting untuk memastikan bahwa asupan energi memadai untuk individu. Penting juga untuk mengakui bahwa kebutuhan energi dapat bervariasi secara signifikan antara individu dan trimester, tergantung pada berbagai variabel, termasuk tingkat aktivitas fisik ibu dan apakah mereka mengharapkan bayi tunggal atau hamil dengan kembar / kelipatan. (de Seymour et al., 2019)

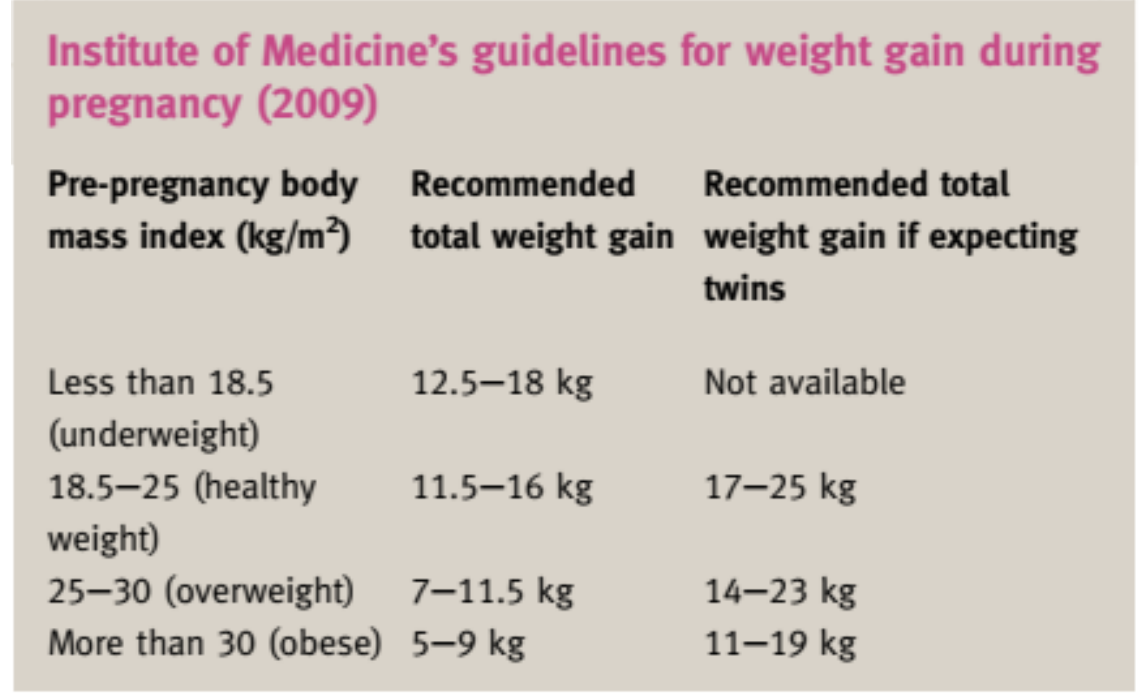

\section{Gambar 1. Rekomendasi Kenaikan Berat Badan Pada Ibu Hamil}

Diet ibu yang sehat dan bervariasi bermanfaat bagi kesehatan dan kesejahteraan ibu dan bayi. Wanita hamil harus fokus pada kualitas diet dan didorong untuk memilih makanan kaya nutrisi yang kaya akan vitamin dan mineral penting. Panduan dan rekomendasi diet secara keseluruhan telah dihasilkan dan dipublikasikan dalam pernyataan Royal College of Obstetricians and Gynecologists (RCOG) untuk membantu pemilihan makanan yang kondusif untuk diet sehat keseluruhan selama kehamilan (lihat di bawah untuk daftar rekomendasi mereka) :

1) Basis makanan pada makanan bertepung seperti kentang, roti, nasi dan pasta.

2) Pilih gandum dan makanan kaya serat jika memungkinkan seperti gandum, kacang-kacangan, lentil, biji-bijian dan biji-bijian, roti gandum, beras merah dan pasta gandum.

3) Makan setidaknya lima porsi buah dan sayuran yang berbeda setiap hari (kentang tidak masuk dalam target ini). Jangan hitung jus buah murni lebih dari satu porsi lima hari.

4) Makan sesedikit mungkin makanan yang digoreng dan hindari minuman yang mengandung banyak gula, dan makanan lain seperti permen, kue dan biskuit yang memiliki kandungan lemak dan / atau gula tinggi.

5) Konsumsi protein setiap hari; pilih daging tanpa lemak saat memilih sumber daging. Lentil, kacang, dan tahu juga merupakan sumber protein yang baik.

6) Bertujuan untuk makan dua porsi ikan seminggu.

7) Makan makanan susu secara teratur tetapi pilihlah varietas rendah lemak seperti susu skim atau yogurt rendah lemak.

8) Tetap memperhatikan porsi porsi makanan dan camilan yang dikonsumsi, dan seberapa sering makan.

9) Selalu makan sarapan. Selain rekomendasi yang dirancang untuk membantu hamil 
Wanita mengikuti diet sehat secara keseluruhan, ada beberapa kunci yang patut mendapat perhatian khusus. Pertama-tama perlu dicatat bahwa penyerapan dan metabolisme berbagai nutrisi penting dari makanan dan dari toko ibu meningkat secara signifikan selama kehamilan. Dengan demikian, meskipun kebutuhan nutrisi meningkat karena tuntutan kehamilan, untuk banyak nutrisi, rekomendasi diet tidak melebihi rekomendasi untuk wanita yang tidak hamil. Namun, sangat penting untuk menekankan kepada wanita hamil pentingnya bertujuan untuk memenuhi rekomendasi. (de Seymour et al., 2019)

Franca Marangoni dalam artikelnya berjudul Maternal Diet and Requirements in pregnant and breastfeeding. An Italian consensus document menjelaskan bahwa persyaratan kalori untuk wanita sehat dengan berat badan normal dengan gaya hidup cukup aktif,mengalami peningkatan moderat selama kehamilan (tergantung pada tahap kehamilan), yang dapat dipenuhi dengan sedikit peningkatan asupan energi, dalam keseimbangan seimbang antara makronutrien dalam rekomendasi pedoman nutrisi. Kelebihan kalori dan makronutrien selama kehamilan mungkin, pada kenyataannya, sama merusaknya seperti kekurangan mereka, terutama pada wanita yang kelebihan berat badan dan obesitas, dengan peningkatan risiko keguguran, diabetes gestasional, pre-eklampsia dan juga obesitas dan diabetes tipe 2 bagi mereka. anak-anak di masa dewasa. Selain itu, selama menyusui hanya peningkatan moderat dalam kebutuhan energi ibu diperlukan untuk produksi ASI. RDA Italia 2014, secara khusus, menunjukkan persyaratan tambahan 69 kkal / hari untuk yang pertama trimester, $266 \mathrm{kkal} /$ hari untuk yang kedua dan $496 \mathrm{kkal} /$ hari pada trimester ketiga kehamilan (dengan total tambahan $76.530 \mathrm{kkal}$ tambahan). Jumlah yang sangat mirip telah ditetapkan oleh EFSA (70 kkal / hari pada trimester pertama menjadi 260 dan $500 \mathrm{kkal} /$ hari, masing-masing), dengan peningkatan sekitar $500 \mathrm{kkal} /$ hari selama 6 bulan pertama eksklusif menyusui.(Marangoni et al., 2016)

Bukti ilmiah yang sangat keras mendukung pentingnya gaya hidup dan kebiasaan diet (dengan memadai asupan mikronutrien) selama kehamilan dan menyusui, untuk status kesehatan wanita dan keturunan mereka. Konsumsi makanan yang bervariasi dan seimbang dari periode prakonsepsi sangat penting untuk memastikan kesejahteraan ibu dan hasil kehamilan yang baik. Bahkan di negara-negara yang paling maju, asupan makanan khusus dalam kehamilan dan menyusui sering tidak memadai. Sehubungan dengan populasi Italia, data yang tersedia menunjukkan bahwa asupan nutrisi yang dipilih sering tidak cukup oleh kedua kelompok populasi yang dipilih dan oleh wanita hamil dan menyusui. Ini khususnya berlaku untuk DHA, zat besi, yodium, kalsium, asam folat, dan vitamin D. Mikronutrient yang dibutuhkan secara khusus :

Asam folat: ada kebutuhan untuk melengkapi diet ibu selama kehamilan, melalui fortifikasi makanan (dalam diet yang tepat) dan melalui penggunaan suplemen pada periode prakonsepsi, sesuai dengan pedoman nasional dan internasional.

Vitamin D: tidak ada konsensus homogen pada asupan yang direkomendasikan [98]; di Italia, dokumen konsensus baru-baru ini yang diterbitkan oleh Societies of Pediatrics menekankan tingginya prevalensi defisiensi dan pentingnya profilaksis juga selama kehamilan dan menyusui.

Zat Besi: walaupun ada kesepakatan umum tentang manfaat suplementasi sistematis pada populasi berisiko tinggi anemia selama kehamilan, berbagai negara memberikan rekomendasi berbeda; secara umum, suplementasi zat besi harus diputuskan berdasarkan penilaian klinis individu.

Yodium: asupan yang memadai harus dipastikan sepanjang kehamilan, mis., Dengan menggunakan makanan yang kaya akan yodium dan garam beryodium.

Kalsium: sebagian besar populasi wanita subur di Eropa (dan Italia) tidak mencapai nilai optimal; Selain itu, perhatian khusus harus diberikan pada ketersediaan hayati dari makanan yang berbeda.

DHA: manfaat selama kehamilan dan menyusui dikonfirmasi oleh penelitian terbaru; asupan yang tidak memadai terkait dengan konsumsi rendah ikan yang kaya omega-3.

Dari sudut pandang gizi, perhatian khusus harus diberikan kepada wanita yang mengandung anak usia yang mengikuti diet eksklusi, terutama selama kehamilan dan menyusui, karena meningkatnya risiko tidak mencapai pasokan nutrisi yang memadai untuk mendukung kesehatan ibu dan bayi. Kasus spesifik yang memerlukan pemeriksaan klinis dan intervensi yang ditargetkan pada periode perinatal termasuk wanita dengan masalah berat badan (kurang berat badan atau kelebihan berat badan / obesitas), perokok, remaja, ibu 
yang memiliki kehamilan ganda atau dekat, dan mereka dengan hasil kehamilan sebelumnya yang tidak menguntungkan.(Marangoni et al., 2016)

\section{KESIMPULAN}

Wanita hamil harus fokus pada kualitas diet dan didorong untuk memilih makanan kaya nutrisi yang kaya akan makronutrint maupun micronutrient. Mitos makan untuk berdua (ibu dan janin) harus dihilangkan, rekomendasi gizi seimbang disesuiakan dengan kebutuhan nutrisi selama hamil sesuai dengan indeks massa tubuh ibu sebelum hamil.

\section{DAFTAR PUSTAKA}

de Seymour, J. V., Beck, K. L., \& Conlon, C. A. (2019). Nutrition in pregnancy. Obstetrics, Gynaecology and Reproductive Medicine, 29(8), 219-224. https://doi.org/10.1016/j.ogrm.2019.04.009

Health, M. (2006). Food and nutrition guidelines for healthy pregnant and breastfeeding women. https://doi.org/10.1055/s-2001-15465

Kementerian Kesehatan RI. (2018). Hasil Utama Riset Kesehatan Dasar (RISKESDAS). 44(8), 1-200. https://doi.org/10.1088/1751-8113/44/8/085201

Koletzko, B., Godfrey, K. M., Poston, L., Szajewska, H., Van Goudoever, J. B., De Waard, M., ... Zalewski, B. M. (2019). Nutrition during pregnancy, lactation and early childhood and its implications for maternal and long-term child health: The early nutrition project recommendations. Annals of Nutrition and Metabolism, 74(2), 93-106. https://doi.org/10.1159/000496471

Marangoni, F., Cetin, I., Verduci, E., Canzone, G., Giovannini, M., Scollo, P., ... Poli, A. (2016). Maternal diet and nutrient requirements in pregnancy and breastfeeding. An Italian consensus document. Nutrients, 8(10), 1-17. https://doi.org/10.3390/nu8100629

Mintarsih, S. (2008). Berat badan dan nutrisi pada wanita hamil. Jurnal Kesehatan Profesional Islami, 3. Retrieved from http://ejournal.stikespku.ac.id/index.php/mpp/article/view/39/35

Oleh, S., \& Nim, M. (2013). FAKTOR-FAKTOR YANG MEMPENGARUHI STATUS GIZI IBU HAMIL PADA MASA KEHAMILAN YANG.

Ribeiro Neves, P. A., Ramalho, A., De Carvalho Padilha, P., \& Saunders, C. (2014). The role of prenatal nutrition assistance on the prevalence of night blindness in pregnant adults. Nutricion Hospitalaria, 29(5), 1132-1140. https://doi.org/10.3305/nh.2014.29.5.7241

Syari, M., Serudji, J., \& Mariati, U. (2015). Peran Asupan Zat Gizi Makronutrien Ibu Hamil terhadap Berat Badan Lahir Bayi di Kota Padang. Jurnal Kesehatan Andalas, 4(3), 729-736. https://doi.org/10.25077/jka.v4i3.355

Wulandari, devyana dyah. (2017). MTPH Journal. Volume 01 Nomor 01 Tahun 2017. ANALISA KESADAHAN TOTAL DAN KADAR KLORIDA AIR DI KECAMATAN TANGGULANGIN SIDOARJO Devyana, 01, 42-51. 